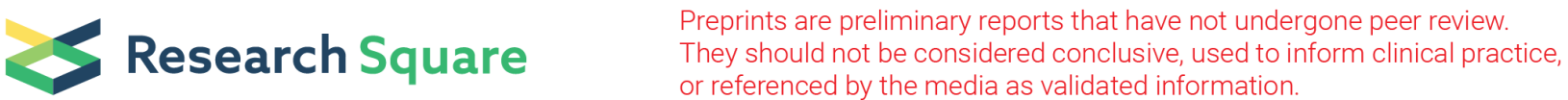 \\ Effect of temperature on the residual shear strength of fine grained soil
}

Marcin Witowski ( $\square$ m.witowski@itb.pl)

Instytut Techniki Budowlanej https://orcid.org/0000-0001-6178-3852

\section{Witold Bogusz}

Instytut Techniki Budowlanej

\section{Research Article}

Keywords: Strength \& testing of materials, Energy, Landslides.

Posted Date: May 27th, 2021

DOl: https://doi.org/10.21203/rs.3.rs-309470/v1

License: (c) (i) This work is licensed under a Creative Commons Attribution 4.0 International License. Read Full License 


\section{Abstract}

The impact of low-range temperature variation on the residual shear strength parameters has been investigated. For this purpose, a standard ring shear apparatus has been subjected to low-cost modifications and equipped with thermoelectric temperature control system constructed in-house. This allowed to conduct a series of tests for clay samples at temperatures of $5^{\circ} \mathrm{C}$ and $20^{\circ} \mathrm{C}$, which is a typical range of variation for thermo-active structures during heat extraction. In order to distinguish the impact of temperature from the natural variability of the soil samples, additional temperature changes during shearing were performed, after residual strength had been reached. The obtained results revealed an observable impact of the temperature change on the residual shear strength of tested clay; however, the variance has been close to the resolution of the measurement sensor and within the range comparable to the natural variability of fine-grained soils. Therefore, low-range temperature changes can be considered as negligible in regard to the residual shear strength parameters.

\section{Introduction}

For the majority of problems encountered in geotechnical engineering, the impact of temperature on soil behaviour may be easily disregarded, while the assumption of consistency of parameters is justified. However, there are a number of problems when the temperature variation has to be acknowledged and it might have to be accounted for in the design. These problems may range from relatively hightemperature exposure $\left(70-100^{\circ} \mathrm{C}\right)$, in the case of nuclear waste repositories (Dupray et al., 2013) or underground high-voltage power lines (Kroener et al., 2014; Ocłoń et al., 2015), to low-range differences, typical for seasonal weather changes (Subramanian et al., 2017) or, the most notably investigated in recent years, the utilization of shallow geothermal energy (Brandl, 2006). Various aspects of hightemperature exposure on soil properties have been investigated rather extensively so far (Tanaka et al., 1997; Hueckel et al., 2009), where the temperature impact is the most noticeable. Therefore, a growing number of recent research activities focused on the latter case, as the implementation of ground source heat pumps (GSHP) becomes a common practice; such systems are often incorporated into structural elements to be used as the thermo-active structures. Nowadays, geotechnical structures investigated for thermal activation include mostly: piles (Bourne-Webb et al., 2009; Amatya et al., 2012; Loveridge and Powrie, 2012), diaphragm walls (Di Donna et al., 2017; Sterpi et al., 2017), and tunnels (Franzius and Pralle, 2011; Di Donna and Barla, 2016). Although their popularity increases rapidly, various uncertainties involved in their design still have to be addressed. One of such issues is a possible change of shear strength of the soil when it is subjected to temperature variation.

The impact of temperature change on peak shear strength parameters has been investigated by a number of researchers (Batenipour et al., 2014; de Groot et al., 2015; Di Donna et al., 2016; Yavari et al., 2016; $\mathrm{Ng}$ et al., 2017). The influence of this factor on various other parameters, such as consolidation properties, for example, was also a subject of some studies (Tsutsumi and Tanaka, 2012; Dalla Santa et al., 2016). Furthermore, novel testing approaches have been developed in recent years, as well, to take this issue into account (Murphy and McCartney, 2014; Pei et al., 2015). Nevertheless, the reliability 
implications associated with possible temperature impact on soil shear strength have been of most concern, for various reasons and under different conditions.

Batenipour et al. (2014) performed triaxial tests at the temperatures of $3^{\circ} \mathrm{C}$ and $21^{\circ} \mathrm{C}$ to verify whether tests at normal laboratory conditions $\left(21^{\circ} \mathrm{C}\right)$ can be applicable to those in cold climate regions with average temperature of $3^{\circ} \mathrm{C}$. It was concluded that the friction angle did not vary with the temperature, confirming the earlier findings of Graham et al. (2001). In comparison, the majority of the other studies were conducted with the use of direct shear apparatus. De Groot et al. (2015) investigated the change of shear strength parameters of clay and sand samples at the temperatures of $20^{\circ} \mathrm{C}$ and $40^{\circ} \mathrm{C}$. For clays, they have noticed a small reduction of shear resistance with the temperature increase; however, it was deemed as insignificant. Similarly, Di Donna et al. (2016) performed tests at temperatures ranging from $20^{\circ} \mathrm{C}$ to $60^{\circ} \mathrm{C}$, for both, sand and clay specimens, with emphasize given to the investigation of the soilconcrete interface and cyclic behaviour. It was concluded that, during the tests, some increase in adhesion with the increase of temperature had occurred for clay-concrete interface, but with slight reduction of the friction angle. This phenomenon has been explained by thermal consolidation of the clay. Conversely, for sand-concrete interface, no particular effects on shear strength were noticed. Correspondingly, Yavari et al. (2016) tested clay, sand, and clay-concrete interface, at the temperatures of $5^{\circ} \mathrm{C}, 20^{\circ} \mathrm{C}$ and $40^{\circ} \mathrm{C}$. In this study, a small impact on the friction angle had also been observed, but without any clear trend; it lead to a conclusion that this range of temperature variations has negligible effects on the shear strength parameters. Finally, $\mathrm{Ng}$ et al. (2017) had performed tests at temperatures of $20^{\circ} \mathrm{C}$ and $60^{\circ} \mathrm{C}$, at different suction pressures. Without suction, negligible thermal effects were observed as well, with an increased impact on peak shear strength as the suction pressure increased.

Among the abovementioned studies, Di Donna et al. (2016) and Yavari et al. (2016) also emphasized the problem of possible cyclic degradation associated with the temperature variation, especially, during exploitation of thermally-activated geostructures, which may operate at the temperatures between $5^{\circ} \mathrm{C}$ and $60^{\circ} \mathrm{C}$. This issue had been investigated to some extent by $\mathrm{Ng}$ et al. (2014), whose results showed that cyclic behaviour can be affected by the temperature. Furthermore, this issue may be of some importance for creeping landslides on natural slopes (Eid and Rabie, 2016). Landslide mobility is affected by thermohydro-mechanical behaviour of the soil, where thermal-induced dilation of solid particles or thermally induced pore pressure may have an impact on landslide acceleration (Pinyol et al. 2018). Therefore, as the shear strength parameters of fine-grained soils may decrease to their residual values due to cyclic loading or reaching relatively large strains, the research results presented herein aim to extend current state of knowledge by assessing the impact of temperature change on residual strength parameters.

\section{Experimental Techniques And Material Used}

\subsection{Testing apparatus and its modifications}

A standard ring-shear apparatus has been used for the purpose of this study (Head and Epps, 2011; ASTM, 2010). Although there are some commercially available equipment set-ups for soil testing at 
different temperature conditions, as a part of the current study, an application of a low-cost and in-house modification to the existing equipment was undertaken. The standard ring shear apparatus has been modified to accommodate temperature control system. The general set-up is presented at Fig. 1a. A 4 $\mathrm{mm}$ diameter copper tube, forming a spiral, was placed inside the chamber of the ring shear apparatus, with water provided in a closed loop for temperature control. However, the standard testing cell did not allow for this modification due to insufficient space between the wall of the cell and the loading cap for the heat exchanger tube installation. Therefore, the external wall of the cell had to be replaced by a new 3D-printed element, which allowed the copper tubes to be fitted in easily (Fig. 1b). Provided modification has allowed to control the temperature of the soil specimen inside the cell without any extensive alterations to its mechanical parts. Furthermore, as a part of the implemented modification, the cooling system was custom-made for the purpose of this research. It composes of reservoir with two pumps, one for internal and one for external circulation (Fig. 1).

The internal circulation was connected to the main reservoir and the water block, which was bonded with two Peltier modules with the use of thermal adhesive, in order to create a solid-state thermoelectric cooler (TEC). A Peltier element is made of a semi-conductive material and provides an alternative to vapourcompression cooling systems (PCB Heaven, 2009). When subjected to a specific voltage across the device, a specific difference in temperature occurs between the two sides of the element, allowing for accurate temperature control. Under these conditions, one side acts as a cooler, while the other one as a heater. In the system prepared for this study, only a cooling side has been attached to the water block, and two radiators were connected to the heating side in order to dissipate the resulting excess heat. Additionally, ventilators were attached to the radiators to increase the efficiency of the system. A control circuit of TEC has been connected to the temperature sensor located inside the water block.

The second pump has been responsible for the external water circulation system (Fig. 1a), providing cooling agent into the cell of the ring shear apparatus (Fig. 1b) through a thermally-isolated silicon tube. Similarly, the cell has been covered by a $3 \mathrm{~cm}$ layer of thermally isolating foam (Fig. 2a). Temperature measurements inside the cell were taken with the use of a sensor placed below the water surface. Furthermore, initial tests were conducted in order to assess the temperature stabilization time inside the soil sample for the subsequent tests; for this purpose, a sensor was placed in the soil sample to measure temperature during its variation in the TEC system, similarly to target testing program. The obtained results showed that the temperature inside the sample was approximately $2^{\circ} \mathrm{C}$ higher than measured in the cell (Fig. 3a). This issue was probably a result of a heat flux from the uninsulated base of the cell. Therefore, in order to obtain a stable $5^{\circ} \mathrm{C}$ temperature in the sample, a temperature of $3^{\circ} \mathrm{C}$ had to be achieved in the cell. In order to avoid its influence on the shear stress measurements, during the actual tests, the sensor in the sample had been removed and only the one in the cell was used for temperature control, with the necessary correction provided. Conducted investigation proved that the assumed temperature range can be reached, controlled, and stably maintained for the entire duration of the test.

Prior to the tests performed on soil samples, the impact of temperature change on the testing equipment had to be verified. As the temperature induced stress changes were expected to be relatively small, any 
resistance resulting from the apparatus being affected might have had an influence on the obtained results. For this purpose, a support by ball bearings, each $10 \mathrm{~mm}$ in diameter, was used instead of a soil sample during a test (Fig. 2b). It allowed for the rotation of the loading cap with relatively small resistance, which therefore allowed for the measurement of the temperature impact on the shear resistance caused by the apparatus itself. Measuring this self-imposed resistance of the equipment started with the placement of the ball bearing frame and filling the cell with water. After stabilization of measurements during subsequent shearing stage, the temperature was lowered to $5^{\circ} \mathrm{C}$. As presented in Fig. $3 b$, the decrease of temperature did not result in the increase of the measured shear stress. It was concluded that this range of temperature change would have had no significant impact on the test results. Therefore, any measured variations would have been caused only by the temperature-induced changes in the soil sample.

\subsection{Test material, specimen preparation and experimental program}

In the present work, tests were performed on natural clay; the soil sample had been taken in Warsaw, the central part of Poland, from the Pleistocene clay stratum. The grain size distribution of the sample is shown in Fig. 4. The basic soil properties were as follows: liquid limit $L L=68 \%$; plasticity limit $P L=27 \%$; plasticity index $\mathrm{I}_{\mathrm{p}}=41 \%$; with specific gravity of $2.61 \mathrm{~g} / \mathrm{cm}^{3}$. Following the method proposed by Head and Epps (2011), the soil sample was minced and dried at the temperature of $105^{\circ} \mathrm{C}$ to a constant mass. After cooling down the sample, distilled water had been added so that the moisture content was corresponding to the plasticity limit of the soil, and then it was left for 24 hours in order to reach uniform saturation of the sample. Finally, the sample was placed in the cell of the ring apparatus and subjected to consolidation prior to the test. During the test, an angular displacement of $0.048^{\circ}$ per minute has been used, following the recommendations of Head and Epps (2011).

For the purpose of this research, a total of 18 soil samples have been tested, at three different consolidation pressures of $50 \mathrm{kPa}, 100 \mathrm{kPa}$, as well as $200 \mathrm{kPa}$, and at the temperatures of $5^{\circ} \mathrm{C}$ and $20^{\circ} \mathrm{C}$. In order to obtain sufficient repeatability of results and to assess variability between samples at the same conditions, three shear tests were conducted for each temperature level and consolidation stress combination. For the test at $5^{\circ} \mathrm{C}$, TEC system had been activated at the beginning of the consolidation phase and maintained for the entire duration of the test. The temperature of $20^{\circ} \mathrm{C}$ corresponded to the ambient temperature maintained in the laboratory.

For further comparison and assessment, as the ring shear apparatus allows for conducting tests at very large strains, additional three samples were subjected to temperature change only after reaching the residual shear strength. At the consolidation stage, these samples were kept at the ambient temperature of $20^{\circ} \mathrm{C}$ and then sheared until constant shear stress was reached. Then, the temperature was lowered to $5^{\circ} \mathrm{C}$ for the period of 2 hours, and restored to $20^{\circ} \mathrm{C}$, afterwards.

\section{Experimental Results}


The experimental results are presented at Fig. 5. For each of vertical stresses under consideration, the results of a series of three tests are presented for the assessment of the repeatability and the natural variability between these tests.

Figure $5 \mathrm{a}$ contains the results of shear tests conducted at the temperature of $5^{\circ} \mathrm{C}$, which are characterized by very small differences between individual tests. With strain increase, after noticeable peak stresses occur at the beginning, the shear stresses stabilize and reach their residual values. Additionally, Fig. 5b shows vertical displacements during shearing, where initial contraction of the sample can be noticed at the beginning of the test, leading to the stabilization of vertical displacements at larger shear strains. Although the vertical displacements increased with the increase of the normal stress, for samples tested at $200 \mathrm{kPa}$, they are lower than for those tested at $100 \mathrm{kPa}$.

The results obtained at the temperature of $20^{\circ} \mathrm{C}$ are presented at Fig. $5 \mathrm{c}$. Comparable repeatability of results can be noticed as for the tests at $5^{\circ} \mathrm{C}$; similarly, the peak strength is followed by gradual stabilization at residual stresses as the shear strain increases. Also in this case, a noticeable contraction occurs with the increase of horizontal strains, as presented in Fig. 5d. Here, however, vertical displacements at normal stresses of $100 \mathrm{kPa}$ and $200 \mathrm{kPa}$ are comparable and reach approximately 0.15 $\mathrm{mm}$. Generally, values of vertical displacements at $5^{\circ} \mathrm{C}$ and $20^{\circ} \mathrm{C}$ are of the same order of magnitude.

Figure 6 presents failure envelopes at residual stresses for tests at both temperature levels that were investigated. The influence of temperature variation on the angle of shear resistance is evident, but negligible as the decrease of less than $3 \%$ was observed with the decrease of the temperature.

Furthermore, the impact of temperature change on the shear stresses is presented in Fig. 7. A noticeable but temporary increase in shear stresses can be seen with the decrease of temperature from $20^{\circ} \mathrm{C}$ to $5^{\circ} \mathrm{C}$, when imposed during shearing. Some trend between the increase of the shear stress and the applied normal stress can be observed, as this increase is approximately equal to $0.5 \mathrm{kPa}$ at $50 \mathrm{kPa}, 1.0 \mathrm{kPa}$ at $100 \mathrm{kPa}$, and $1.5 \mathrm{kPa}$ at $200 \mathrm{kPa}$. The small initial temperature-induced peak returns to the stress value which preceded the temperature change, although the time period for this return increases for larger stresses.

In order to allow a more in-depth analysis of these results, Fig. 7 also show the vertical displacements in relation to the imposed temperature variation, at different normal stresses. Similarly to the shear stresses, a change in the height of the sample occurred following the temperature decrease, as well. However, this phenomenon ceased, as the temperature returned to its initial value of $20^{\circ} \mathrm{C}$.

\section{Discussion And Conclusions}

Provided modification to the standard ring shear apparatus allowed for the execution of the assumed testing program on clay samples subjected to temperature change. Especially, the TEC system utilized for the purpose of the study proved to be effective in the targeted range of temperature variation, as it allowed for accurate control and maintenance of the conditions during the test. Although there already 
are commercially available solutions, which allow to perform tests at varying temperatures, they often are expensive and rarely used outside major research institutions and laboratories. Modifications introduced to the existing apparatus may be an alternative as a low-cost solution, therefore contributing to the increase of availability of more advanced laboratory testing infrastructure; the cost of the necessary raw materials was below $€ 100$. However, to validate whether temperature change would not have had an impact on the anticipated outcome, a series of tests was performed with soil replaced by ball bearings; the provided modifications proved sufficient for the planned testing program.

The results obtained from a series of tests on the soil samples revealed an observable impact of the temperature change on the residual shear strength of tested clay; however, the variance has been close to the resolution of the measurement sensor and within the range comparable to the natural variability of this fine-grained soil. Generally, the observed impact was in line with the results obtained by other researchers for peak strength parameters (Batenipour et al., 2014; de Groot et al., 2015; Di Donna et al., 2016; Yavari et al., 2016; $\mathrm{Ng}$ et al., 2017). Such small variations are rather insignificant for most practical purposes. Therefore, it can be concluded that low-range temperature changes can be considered as negligible in regard to residual shear strength parameters. The magnitude of variations is well within the range of natural variance that can be observed in most clays. From practical point of view, such variations generally do not have to be explicitly accounted for in the design of thermoactive structures. Additionally, the conclusion of Batenipour et al. (2014) that the test results obtained at normal laboratory conditions offer sufficient reliability for soils in cold climate regions at temperatures above freezing, can be extended to the residual strength parameters of fine grained soils.

Some limited impact has been noticed when temperature change was introduced during shearing, as residual shear stresses were reached. However, with the progressive shearing, this influence deteriorated. This may suggest the connection to possible thermal consolidation, similar to a phenomenon noticed by Di Donna et al. (2016) or investigated by Pinyol et al. (2018). This issue, as well as the impact of heating on residual shear strength, will be considered for further study in the future.

\section{Declarations}

\section{Acknowledgement}

This work has been funded by the Polish Ministry of Science and Higher Education through a statutory research fund provided for the Polish Building Research Institute (project no. NZK-69). The research has been inspired by and conducted in the framework of the COST Action GABI TU 1405 - European network for shallow geothermal energy applications in buildings and infrastructures. Furthermore, the authors would like to thank Monika Niemyjska and Olga Wesołowska for their technical support.

\section{References}


Amatya BL, Soga K, Bourne-Webb PJ, Amis T and Laloui L (2012) Thermo-mechanical behaviour of energy piles, Géotechnique 62(6): 503-519, doi:10.1680/geot.10.P.116

ASTM (2010) D7608-10 Standard Test Method for Torsional Ring Shear Test to Determine Drained Fully Softened Shear Strength and Nonlinear Strength Envelope of Cohesive Soils (Using Normally Consolidated Specimen) for Slopes with No Preexisting Shear Surfaces, ASTM International.

Batenipour H, Alfaro M, Kurz D and Graham J (2014) Deformations and ground temperatures at a road embankment in northern Canada, Canadian Geotechnical Journal 51(3): 260-271, doi:10.1139/cgj-20120425

Bourne-Webb PJ, Amatya BL, Soga K, Amis T, Davidson C and Payne P (2009) Energy pile test at Lambeth College, London: geotechnical and thermodynamic aspects of pile response to heat cycles. Géotechnique 59(3): 237-248, doi:10.1680/geot.2009.59.3.237

Brandl H (2006) Energy foundations and other thermo-active ground structures, Géotechnique 56(2): 81122, doi:10.1680/geot.2006.56.2.81

Dalla Santa G, Galgaro A, Tateo F and Cola S (2016) Modified compressibility of cohesive sediments induced by thermal anomalies due to a borehole heat exchanger, Engineering Geology 202: 143-152, doi:10.1016/j.enggeo.2016.01.011

de Groot M, Muniz M, de la Parra AR and Pardo de Santayana F (2015) Empirical analysis of skin friction under variations of temperature, Geotechnical Engineering for Infrastructure and Development. 26072612, doi:10.1680/ecsmge.60678.vol5.402

Di Donna A and Barla M (2016) The role of ground conditions on energy tunnels' heat exchange, Environmental Geotechnics 3(4): 214-224, doi.org/10.1680/jenge.15.00030

Di Donna A, Ferrari A and Laloui L (2016) Experimental investigations of the soil-concrete interface: physical mechanisms, cyclic mobilization, and behaviour at different temperatures, Canadian Geotechnical Journal 53(4): 659-672, doi:10.1139/cgj-2015-0294

Di Donna A, Cecinato F, Loveridge F and Barla M (2017) Energy performance of diaphragm walls used as heat exchangers, ICE Geotechnical Engineering 170(3): 232-245, doi:10.1680/jgeen.16.00092

Dupray F, Li C and Laloui L (2013) THM coupling sensitivity analysis in geological nuclear waste storage, Engineering Geology 163: 113-121, doi:10.1016/j.enggeo.2013.05.019

Eid HT and Rabie KH (2016) Fully Softened Shear Strength for Soil Slope Stability Analyses, ASCE International Journal of Geomechanics 17(1), doi:10.1061/(ASCE)GM.1943-5622.0000651

Franzius JN and Pralle N (2011) Turning segmental tunnels into sources of renewable energy, Proc. of ICE - Civil Engineering 164(1): 35-40, doi:10.1680/cien.2011.164.1.35 
Graham J, Tanaka N, Crilly T and Alfaro (2001) Modified Cam-Clay modelling of temperature effects in clays, Canadian Geotechnical Journa/38(3): 608-621, doi:10.1139/t00-125

Head KH and Epps R (2011) Manual of soil laboratory testing. Volume 2: Permeability, Shear Strength and Compressibility Tests $3^{\text {rd }}$ Edition, Whittles Publishing, Dunbeath Mill, Scotland.

Hueckel T, Francois B and Laloui L (2009) Explaining thermal failure in saturated clays, Géotechnique 59(3): 197-212, doi:10.1680/geot.2009.59.3.197

Kroener E, Vallati A and Bittelli M (2014) Numerical simulation of coupled heat, liquid water and water vapor in soils for heat dissipation of underground electrical power cables, Applied Thermal Engineering 70: 510-523, doi:10.1016/j.applthermaleng.2014.05.033

Loveridge F and Powrie W (2012) Pile heat exchangers: thermal behavior and interactions, ICE Geotechnical Engineering 66(2): 178-196, doi:10.1680/geng.11.00042

Murphy KD and McCartney JS (2014) Thermal borehole shear device, Geotechnical Testing Journal 37(6): 1040-1055, doi:10.1520/GTJ20140009

$\mathrm{Ng}$ CWW and Zhou C (2014) Cyclic behavior of an unsaturated silt at various suctions and temperatures, Géotechnique 64(9): 709-720, doi:10.1680/geot.14.P.015

$\mathrm{Ng} \mathrm{CWW}, \mathrm{Mu}$ QY and Zhou C (2017) Effects of soil structure on the shear behavior of an unsaturated loess at different suctions and temperatures, Canadian Geotechnical Journal 54(2): 270-279, doi:10.1139/cgj-2016-0272

Ocłoń P, Cisek P, Pilarczyk M and Taler D (2015) Numerical simulation of heat dissipation processes in underground power cable system situated in thermal backfill and buried in a multilayered soil, Energy Conversion and Management 95: 352-370, doi:10.1016/j.enconman.2015.01.092

PCB Heaven (2009) Peltier Elements Explained. Available from pcbheaven.com/wikipages/The_Peltier_Thermo-Element [accessed 12 March 2018]

Pei L, Ruhaak W, Stegner J, Bar K, Homuth S, Mielke P and Sass I (2015) Thermo-triax: an apparatus for testing petrophysical properties of rocks under simulated geothermal reservoir conditions, Geotechnical Testing Journa/ 38(1): 119-138, doi:10.1520/GTJ20140056

Pinyol NM, Alvarado M, Alonso EE and Zabala F (2018) Thermal effects in landslide mobility, Géotechnique 68(6): 528-545, doi:10.1680/jgeot.17.P.054

Sterpi D, Coletto A and Mauri L (2017) Investigation on the behaviour of a thermo-active diaphragm wall by thermo-mechanical analyses, Geomechanics for Energy and the Environment 9: 1-20, doi:10.1016/j.gete.2016.10.001 
Subramanian SS, Ishikawa T and Tokoro T (2017) Stability assessment approach for soil slopes in seasonal cold regions, Engineering Geology 221: 154-169, doi:10.1016/j.enggeo.2017.03.008

Tanaka N, Graham J and Crilly T (1997) Stress-strain behavior of reconstituted illitic clay at different temperatures, Engineering Geology 47(4): 339-350, doi:10.1016/S0013-7952(96)00113-5

Tsutsumi A and Tanaka H (2012) Combined effects of strain rate and temperature on consolidation behavior of clayey soils, Soils and Foundations 52(2): 207-215, doi:10.1016/j.sandf.2012.02.001

Yavari N, Tang AM, Pereira JM and Hassen G (2016) Effect of temperature on the shear strength of soils and soil/structure interface, Canadian Geotechnical Journal 53(7): 1186-1194, doi:10.1139/cgj-20150355

\section{Figures}



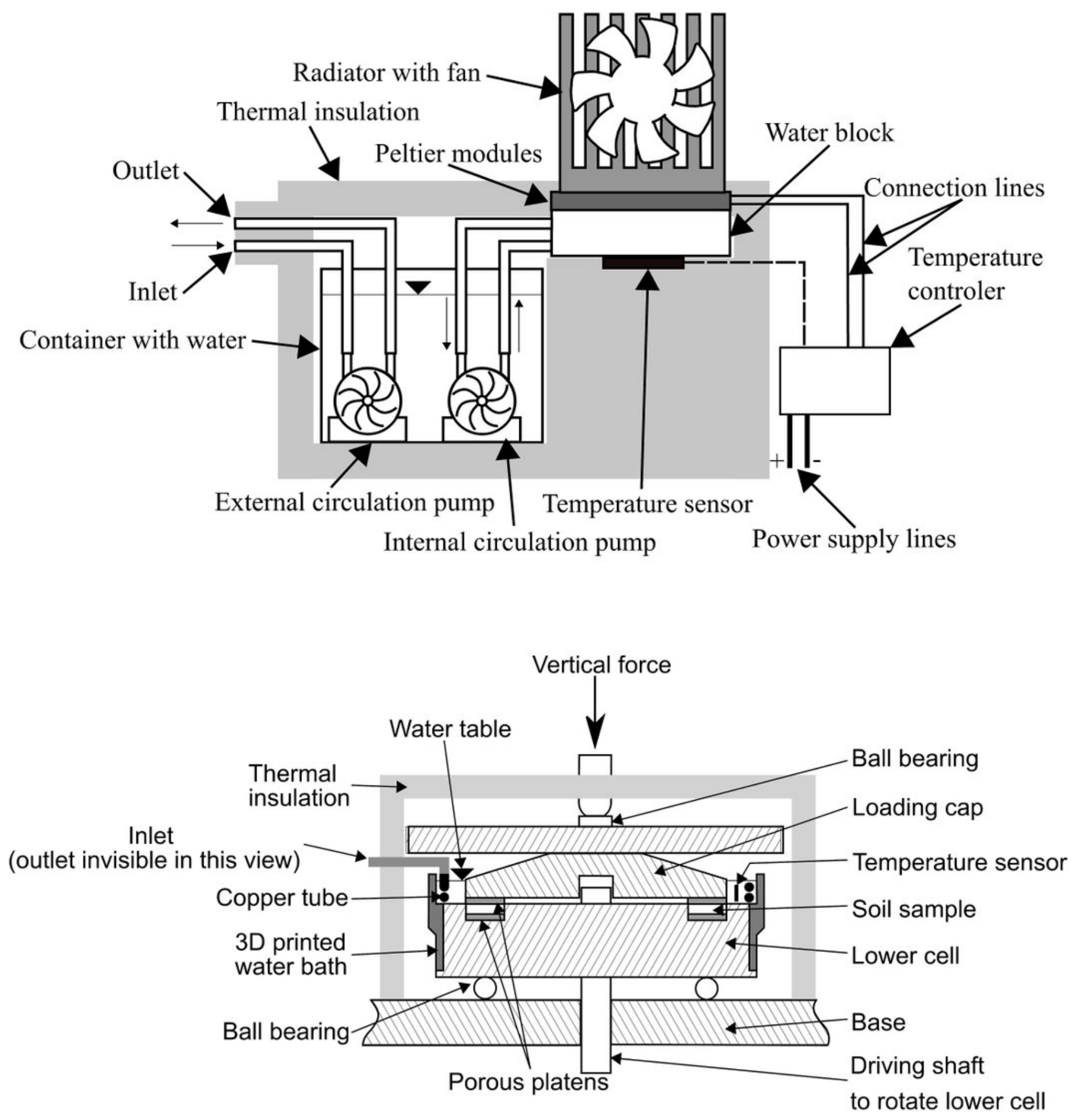

Figure 1

Testing apparatus - temperature control system (a), the modified ring shear apparatus (b) 

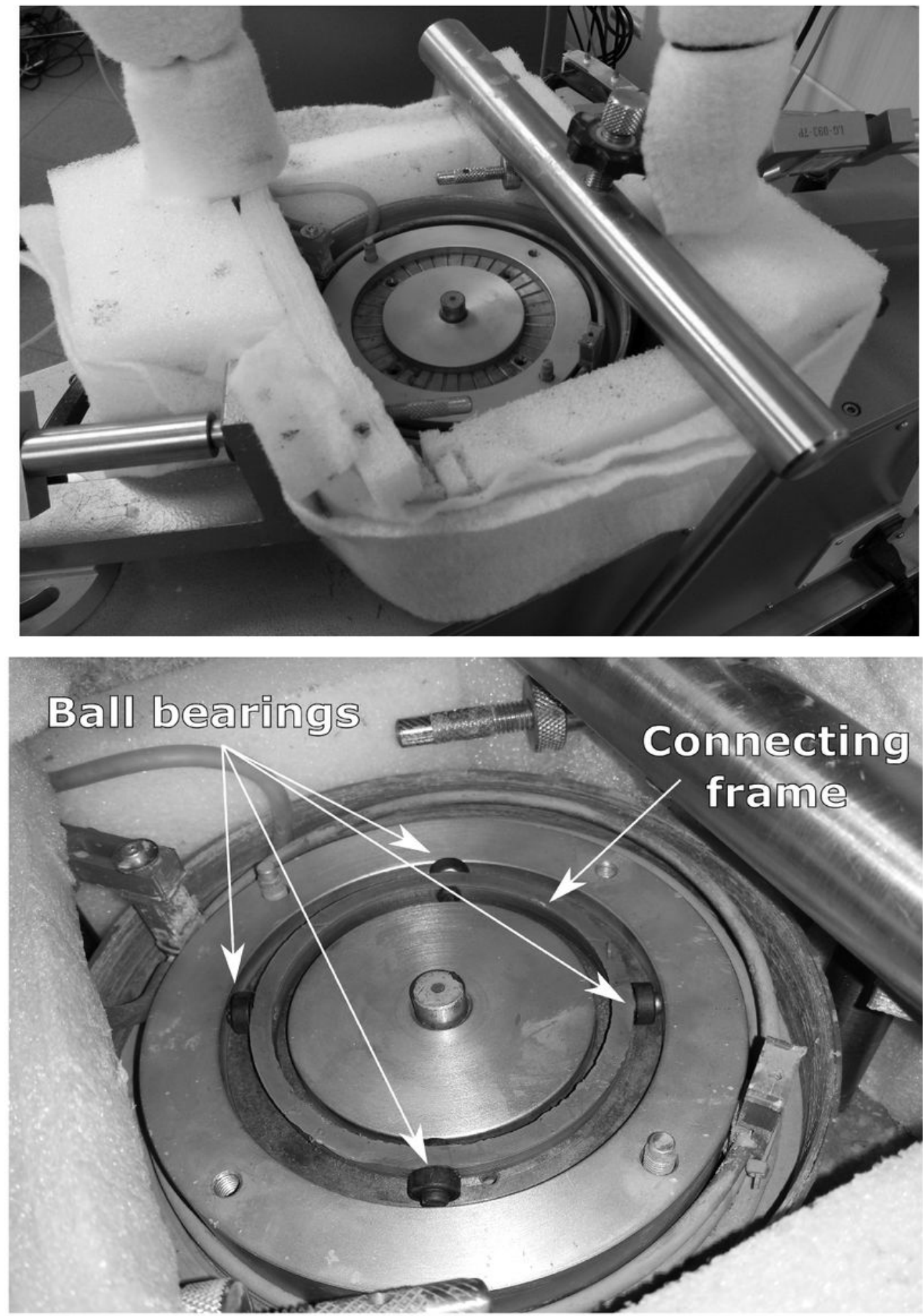

Figure 2

View on - the modified testing chamber (a), the support by ball bearings (b) 

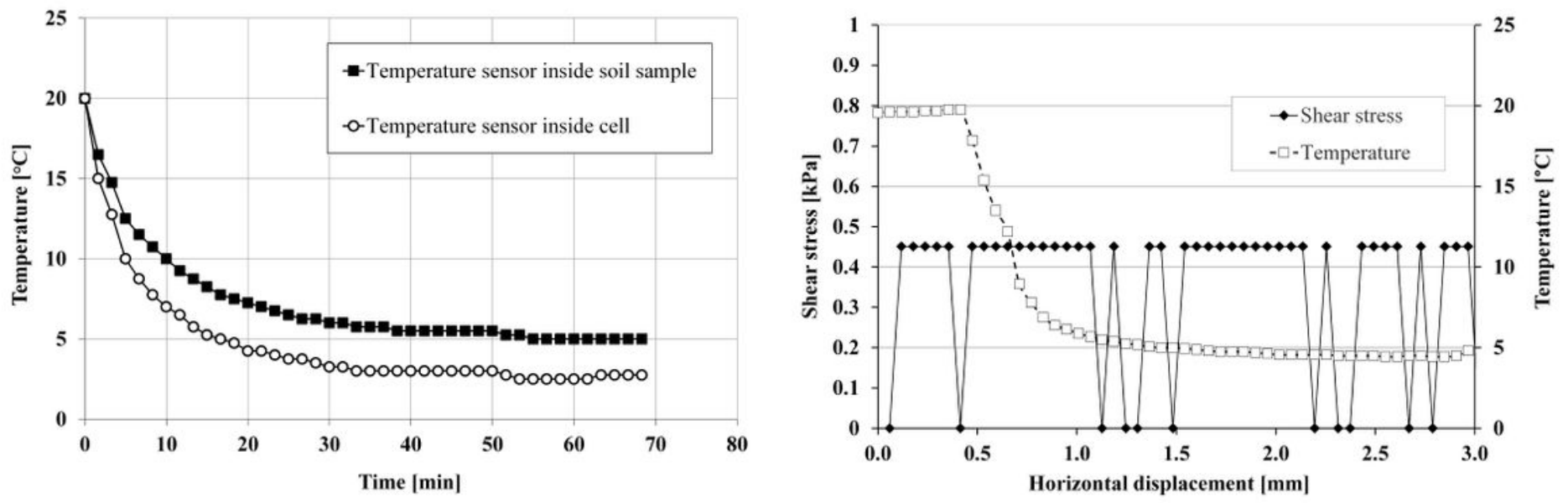

Figure 3

Impact of temperature - stabilization time (a), the apparatus without soil sample (b)

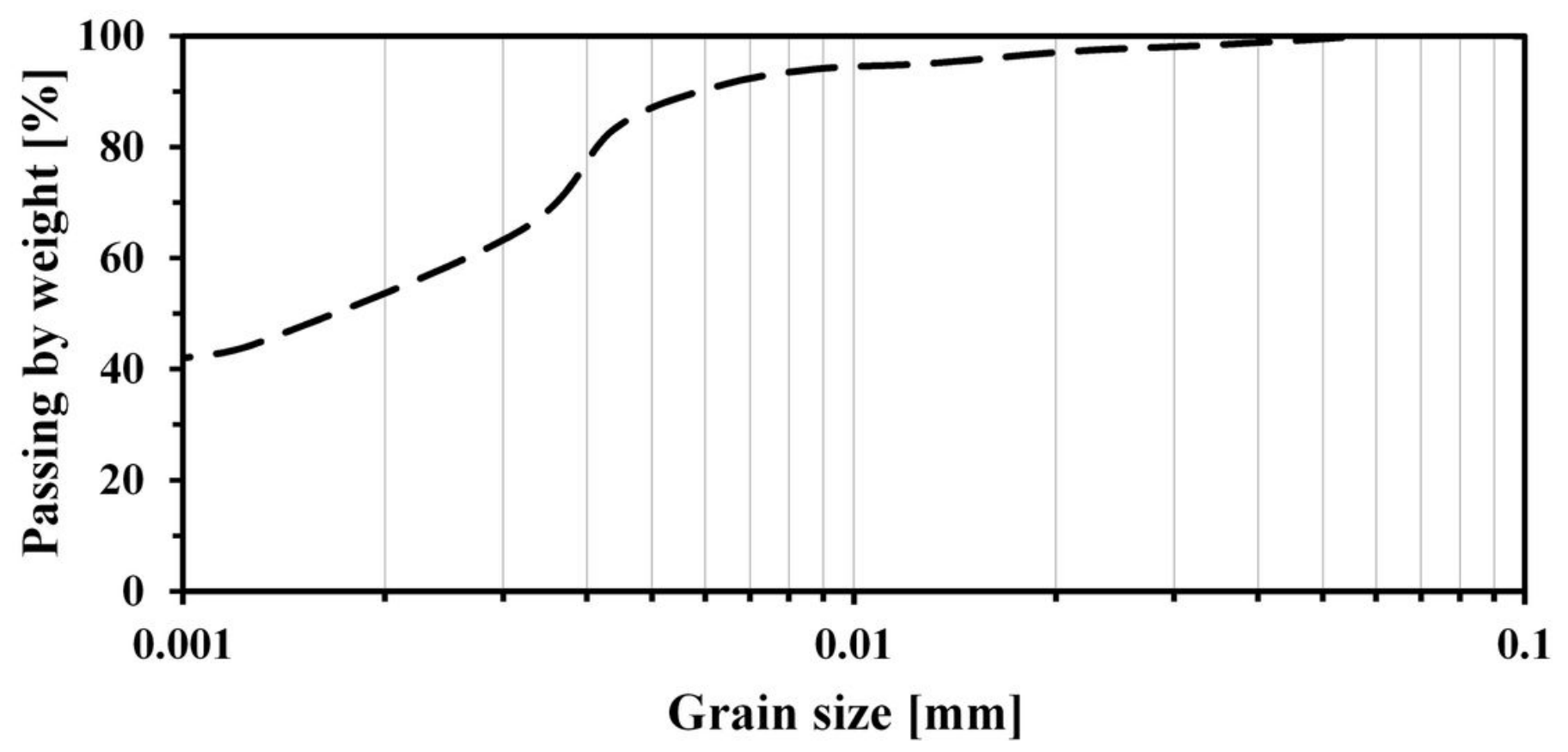

Figure 4

Grain size distribution curve for the tested soil 

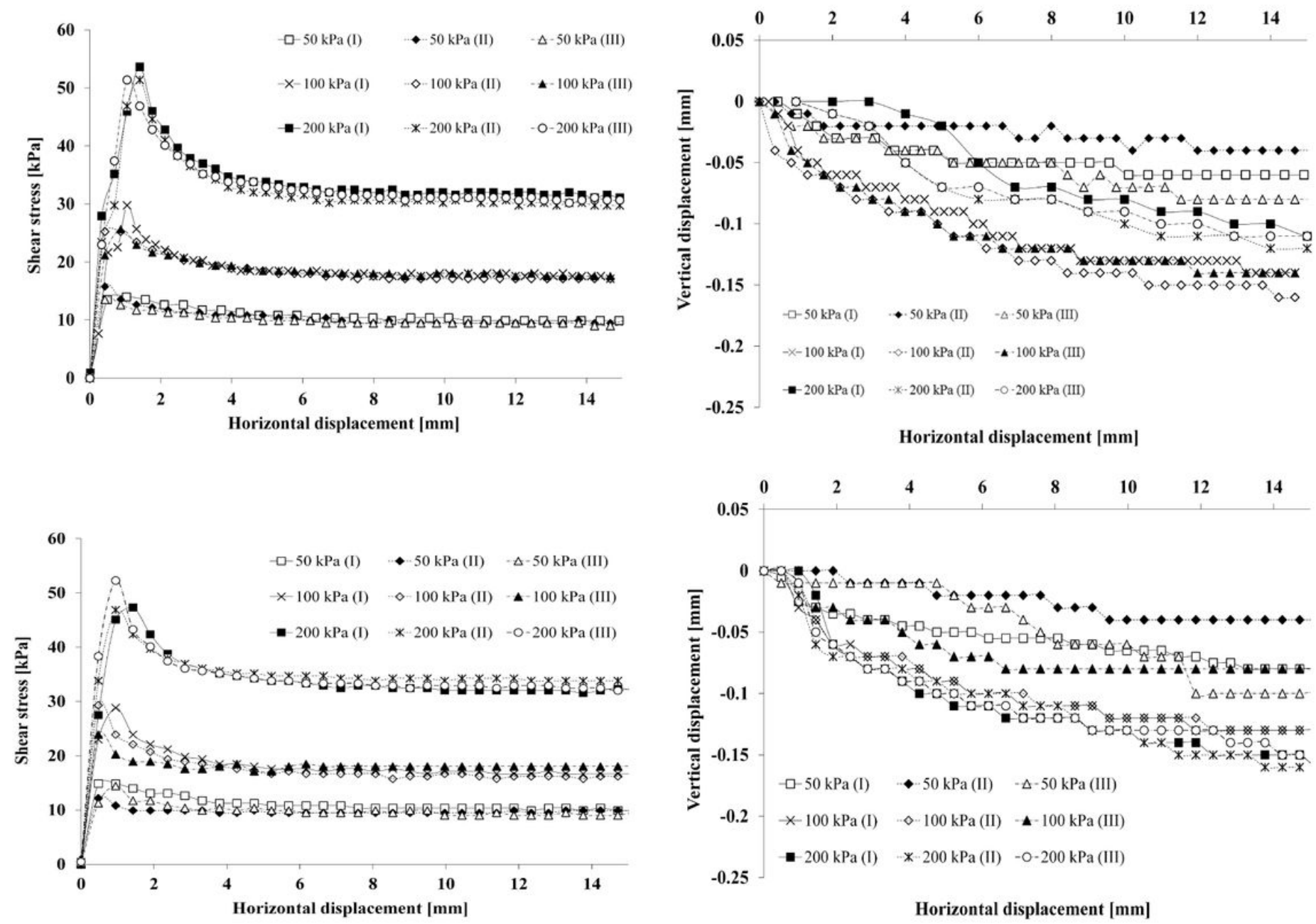

Figure 5

Experimental results - shear stress versus horizontal displacement at $5^{\circ} \mathrm{C}(\mathrm{a})$, vertical displacement versus horizontal displacement at $5^{\circ} \mathrm{C}(\mathrm{b})$, shear stress versus horizontal displacement at $20^{\circ} \mathrm{C}$ (c), vertical displacement versus horizontal displacement at $20^{\circ} \mathrm{C}(\mathrm{d})$ 


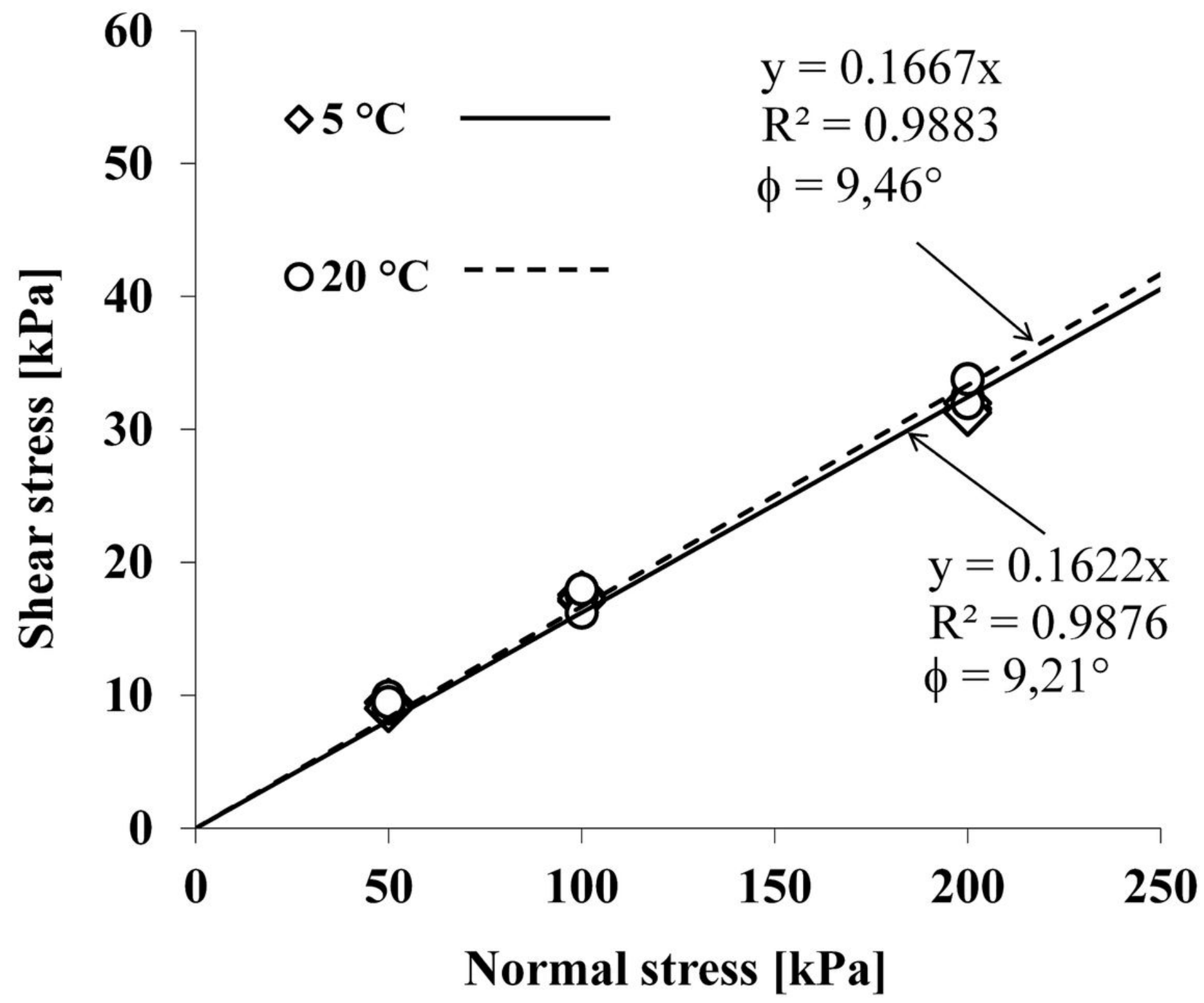

Figure 6

Residual shear strength envelopes at tested temperatures 

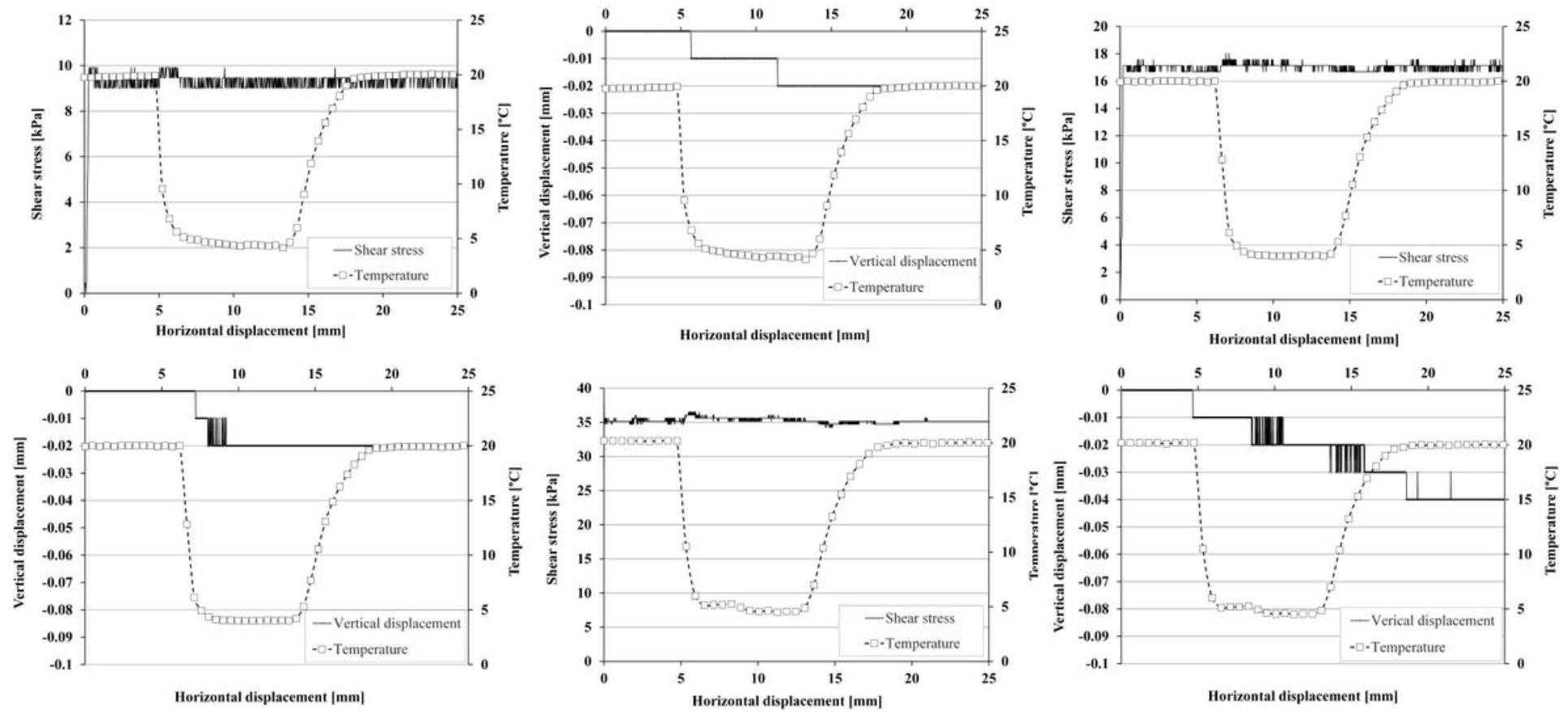

Horizontal displacement [mm]

Figure 7

Impact of temperature change on - residual shear stress at vertical stress of $50 \mathrm{kPa}(\mathrm{a})$, vertical displacement at vertical stress of $50 \mathrm{kPa}$ (b), residual shear stress at vertical stress of $100 \mathrm{kPa}$ (c), vertical displacement at vertical stress of $100 \mathrm{kPa}(\mathrm{d})$, residual shear stress at vertical stress of $200 \mathrm{kPa}$ (e), vertical displacement at vertical stress of $200 \mathrm{kPa}(\mathrm{f})$ 